\title{
Life cycle assessment of fish and prawn production: Comparison of monoculture and polyculture freshwater systems in Brazil
}

\author{
Mateus V. Medeiros ${ }^{\text {a, * }}$, Joël Aubin ${ }^{\text {b }}$, Antonio F.M. Camargo a, c \\ a Centro de Aquicultura da Universidade Estadual Paulista (CAUNESP), 14884-900, Jaboticabal, SP, Brazil \\ ${ }^{\mathrm{b}}$ UMR SAS, INRA, AGROCAMPUS OUEST, 35000 Rennes, France \\ ${ }^{\mathrm{c}}$ Universidade Estadual Paulista - UNESP, Departamento de Ecologia, IB, 13506-900, Rio Claro, SP, Brazil
}

\section{A R T I C L E I N F O}

\section{Article history:}

Received 23 March 2016

Received in revised form

10 April 2017

Accepted 10 April 2017

Available online 12 April 2017

Handling Editor: Cecilia Maria Villas Bôas de Almeida

\section{Keywords:}

Macrobrachium amazonicum

Colossoma macropomum

Aquaculture

Allocation

Uncertainty analysis

\begin{abstract}
A B S T R A C T
This study applied life cycle assessment (LCA) to evaluate and compare environmental impacts of monoculture and polyculture systems in freshwater ponds. Two omnivorous native Brazilian species were used: the fish tambaqui (Colossoma macropomum) and the Amazon River prawn (Macrobrachium amazonicum). Four semi-intensive aquaculture systems (at an experimental level) were established and studied: monoculture of C. macropomum (MM), monoculture of M. amazonicum (MA), polyculture in which both species were free in the pond (PF), and polyculture in which C. macropomum was reared in a hapa cage and M. amazonicum was free in the pond (PH). The MM, PF and PH systems were fed fish feed, while MA was fed shrimp feed. Water was not renewed, but added only to replace losses from evaporation and seepage. Seven impact categories were analyzed: climate change, eutrophication, cumulative energy demand, land occupation, acidification, net primary production use and water dependence. Potential impacts of $1 \mathrm{~kg}$ of animal biomass produced by the systems were calculated, as was uncertainty in predictions based on uncertainty in data for the systems. Environmental impacts of each species in the polyculture systems were estimated using system expansion and different allocation approach: mass, energy and economic. PF and MM had the lowest impacts in all impact categories, while MA had the highest. When economic allocation was used, PF had lower impacts than MM per $\mathrm{kg}$ of C. macropomum. The rearing stage itself was the main contributor to eutrophication, land occupation and water dependence. However, feed was the main contributor to acidification and net primary production use in all systems. Only for PH was feed not the most significant contributor to climate change. Productivity and feed conversation ratio were key factors that defined the most efficient system from an environmental viewpoint. Our study demonstrated the advantage of rearing M. amazonicum in a polyculture instead of a monoculture, while no difference was found for C. macropomum. Changing the allocation approach revealed that aquaculture of $M$. amazonicum has lower impacts when the species is reared in polyculture systems. Moreover, aquaculture of native species remains in the early stages, and further development of its production chain may decrease its environmental impacts.
\end{abstract}

(־) 2017 Elsevier Ltd. All rights reserved.

\section{Introduction}

Fed aquaculture is increasingly used to produce high-value fish and crustacean species (FAO, 2014). However, its nutrient efficiency remains moderate, since only $30 \%$ of the total nitrogen $(\mathrm{N})$ and phosphorus $(\mathrm{P})$ delivered to the system is recovered in biomass

\footnotetext{
* Corresponding author. CAUNESP, Via de Acesso Prof. Paulo Donato Castellane, s/ n, 14884-900, Jaboticabal, SP, Brazil.

E-mail addresses: mateusvmedeiros@hotmail.com (M.V. Medeiros), joel.aubin@ inra.fr (J. Aubin), afmc@rc.unesp.br (A.F.M. Camargo).
}

(Boyd and Tucker, 1998). The discharge of enriched effluents from aquaculture sites causes environmental pollution and degradation in the receiving water bodies (Boaventura et al., 1997; Jegatheesan et al., 2011). In addition to the discharge, the spread of diseases and escape of farmed species can affect local biodiversity; these impacts are amplified in the case of non-native species (Diana, 2009; Naylor et al., 2000). Domestication of native species and improvements in aquaculture production systems are important steps to achieve sustainable development, especially from an environmental viewpoint. From this perspective, domestication of native species in Brazil is important because the country is a hotspot of biodiversity 
and has a growing aquaculture sector.

Production by Brazilian aquaculture increased by $8.5 \%$ from 2013 to 2014 reaching $561 \mathrm{kt}$ (IBGE, 2014). According to the FAO (2016), it ranked 2nd and 14th in Latin American and global aquaculture production, respectively. Brazil has placed special focus on rearing native species. In particular, the fish Colossoma macropomum, the second most produced species in Brazil, is responsible for nearly $25 \%$ of all national aquaculture production (IBGE, 2014). Domestication of native Brazilian species, however, remains at an early stage. For instance, the freshwater prawn Macrobrachium amazonicum has only small-scale regional production, despite its potential for aquaculture (Moraes-Valenti and Valenti, 2010) and many research studies of its production stages (de Araujo and Valenti, 2007; Maciel and Valenti, 2009).

The focus of this study was to explore the relevance of improving production system efficiency by combining the aquaculture of two species. In polyculture, nutrients not used by one species can be used by the other, and in some cases the presence of one species increases the productivity of the other (Joyni et al., 2011; Wahab et al., 2011). In addition to improvements in nutrient use, the additional product at the end of the cycle provides an economic benefit (Kadir et al., 2007; Whitmarsh et al., 2006). Nevertheless, environmental efficiency of a production system does not rely only on the nutrients retained as biomass; pollutant emissions and fate, and consumption of resources at different stages of the production system, should also be considered.

Life cycle assessment (LCA), an important tool for estimating environmental impacts and identifying their sources (ISO, 2006a, b), has been used to analyze aquaculture production systems around the world (Aubin et al., 2015; Cao et al., 2011; Dekamin et al., 2015; Huysveld et al., 2013; Pelletier and Tyedmers, 2010; Santos et al., 2015). However, to our knowledge, LCA has been applied only once to polyculture systems (Aubin et al., 2015) and rarely to integrated aquaculture and agriculture systems (Efole Ewoukem et al., 2012; Phong et al., 2011), since most LCA studies evaluate monoculture systems. One advantage of LCA is that it allows different products or systems to be compared using the same functional unit. Decisions and assumptions made by LCA practitioners about system boundaries and life cycle inventories, however, may lead to biased comparisons.

To quantify life cycle inventories, most aquaculture LCA studies in the literature used data from commercial units (Dekamin et al., 2015; Jerbi et al., 2012; Pelletier and Tyedmers, 2010), while some relied on questionnaires (Aubin et al., 2015; Bosma et al., 2011) and others designed hypothetical farms based on literature data (Santos et al., 2015). In this study, we performed LCA with data collected during an experiment. The small scale of the experimental units allows better control of system inputs and outputs, and facilitates replication of production scenarios to better understand the influence of controlled factors on system performance.

To determine nutrient fate, the modeling approach designed in this study included emissions to the water and soil, commonly considered in aquaculture LCAs, and added emissions to the air. Although studies have identified gas emissions from aquaculture systems (Gross et al., 2000; Lorenzen et al., 1997), only a few have discussed their importance, especially that of methane, in LCA impact categories in aquaculture systems (Aubin et al., 2015; Phong et al., 2011).

Henriksson et al. (2012) highlight the poor data quality in certain aquaculture LCA studies. Different approaches, such as determining uncertainty, have been developed to increase the level of confidence in LCA inventories (Ciroth et al., 2013; Henriksson et al., 2014); however, uncertainty in input data is often ignored in published studies. Moreover, approaches for allocating environmental impacts of multi-output systems remain under debate.
In our study, robustness of the results is considered using estimates of the uncertainty in and their sensitivity to different approaches for allocating impacts among species produced by polyculture systems. The overall aim of this study is to compare the environmental performance of monoculture and polyculture of $C$. macropomum and $M$. amazonicum, based on experimental results, to highlight challenges of developing multi-species aquaculture.

\section{Material and methods}

Environmental impacts of the aquaculture rearing systems were estimated using LCA in accordance with ISO standards (ISO, 2006a, b).

\subsection{Goal and scope}

The goal of this LCA study was to estimate and compare environmental impacts of polyculture and monoculture rearing systems of two native Brazilian species. The functional unit was $1 \mathrm{~kg}$ of animal biomass (liveweight), and fish and prawn were considered a single output in polyculture systems. This study is based on experimental results designed to compare the efficiency of M. amazonicum and C. macropomum monocultures and polycultures. When allocation was applied to the polyculture systems, outputs were $1 \mathrm{~kg}$ of fish or prawn separately (see section 2.5 Coproduct handling approaches).

The system boundaries used in this study were from "cradle to farm gate" (Fig. 1). The inputs considered for the farm production stage were feed, stocking animals, equipment, infrastructure (ponds and buildings), transport, electricity and water. Emissions to the soil, water and air from the experimental ponds were included. A similar approach was applied to the previous stages of fish fry and prawn post-larvae $(\mathrm{pl})$ production.

\subsection{Experimental aquaculture systems}

The experiment was conducted at the Freshwater Prawn Sector of the Aquaculture Center of UNESP (CAUNESP) in Jaboticabal, São Paulo, Brazil $\left(21^{\circ} 15^{\prime} 18^{\prime \prime} \mathrm{S} ; 48^{\circ} 19^{\prime} 19^{\prime \prime} \mathrm{W}\right)$. Twelve earthen ponds with an area of $110-170 \mathrm{~m}^{2}$ and depth of $0.85-1.19 \mathrm{~m}$ were used during 170 days in the warm season (November 2013 to April 2014). No liming, fertilization or water renewals were performed. Water was added to replace loss from evaporation and seepage. Aeration was provided to all ponds from the third month onwards from 1:30-5:30 a.m. in periods of 60:30 min (on:off); in total, propeller aerators were used for $399 \mathrm{~h}$.

Four systems with three replicates each were tested: I) monoculture of C. macropomum (MM), II) monoculture of M. amazonicum (MA), III) polyculture of C. macropomum and $M$. amazonicum in which both species were free in the pond (PF) and IV) polyculture of $C$. macropomum and $M$. amazonicum in which the fish were reared inside a hapa $\left(4 \mathrm{~m}^{3}\right.$ net cages) and the prawn were free in the pond ( $\mathrm{PH})$. Hapas are net cages, supported by wood, metal or bamboo poles, commonly used to separate individuals of different species or size in the same pond. The $\mathrm{PH}$ system was created to keep fish from eating prawns. In the polyculture systems (PH and PF), prawn pl were stocked one week before fish fry were stocked. Since the prawn pl were produced in the experimental CAUNESP hatchery in Jaboticabal, no transport was required. The fish fry came from a commercial farm located in Presidente Figueiredo, Amazonas, Brazil, and the delivery included transport by air and road. Initial mean prawn pl weight and stocking density were $0.038 \mathrm{~g}$ and $30 \mathrm{pl} \mathrm{m}^{-2}$, respectively, in the MA, PF and PH systems. Initial mean fish fry weight was $1.77 \mathrm{~g}$, and the stocking density was 3 fry $\cdot \mathrm{m}^{-2}$ in the MM and PF systems. 


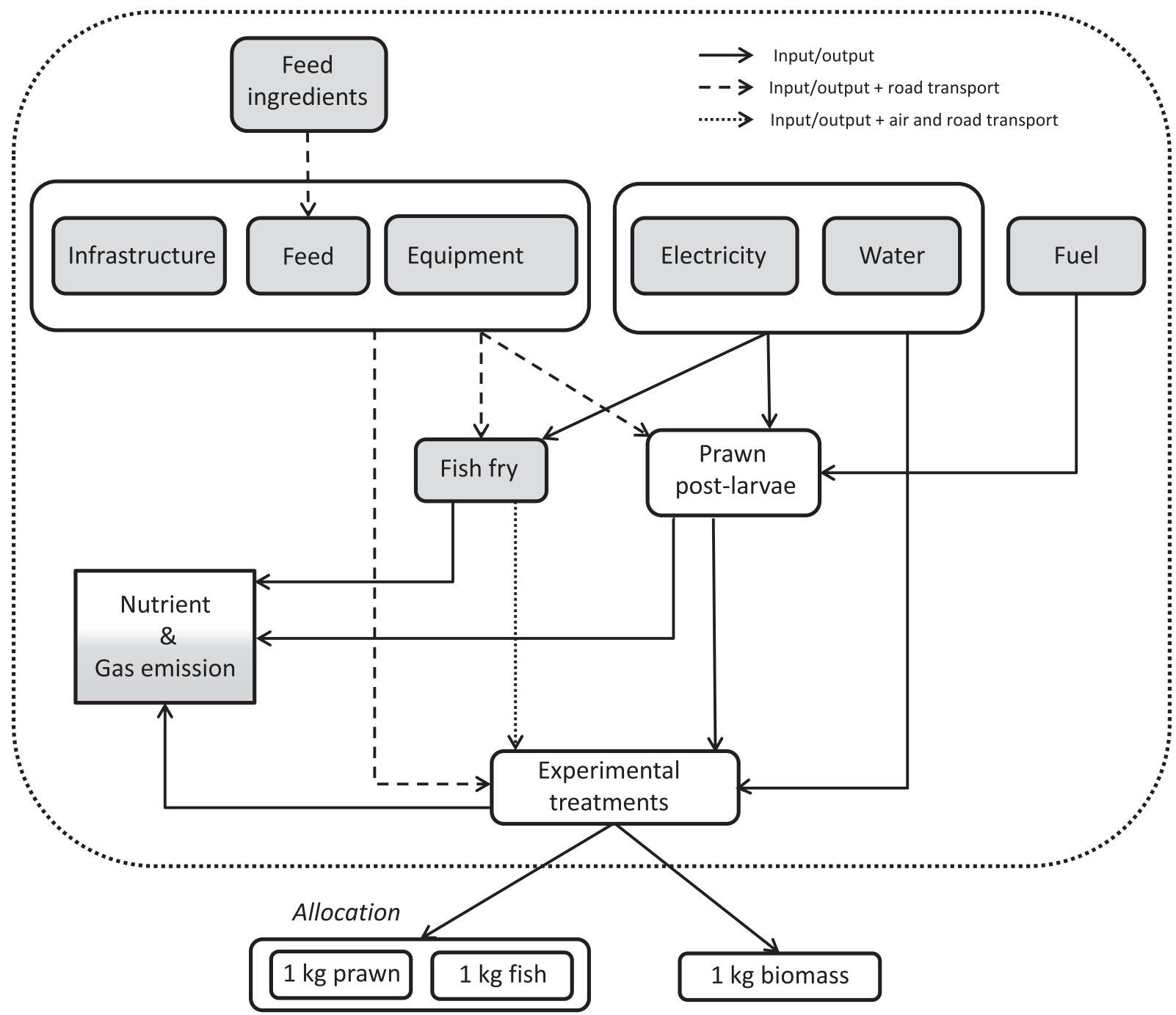

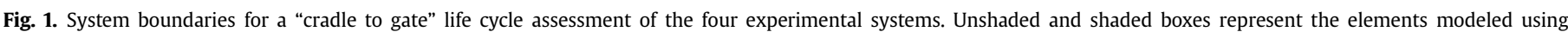
foreground and background data, respectively.

In contrast, the stocking density in the $\mathrm{PH}$ system was 30 fry $\cdot \mathrm{m}^{-3}$ in the hapa, or 0.86 fry $\cdot \mathrm{m}^{-2}$ in relation to the pond surface. Feed was delivered twice a day and adjusted once per month after fish/ prawn sampling. The amount of feed in the PF and PH systems was calculated according to fish biomass. The feed in the PH system was delivered only inside the hapa, while feed in the other systems was spread over the pond surface. Fish in MM, PF and PH systems were fed three types of fish feed (32-45\% crude protein, 4.5-7.0\% lipid), and prawn in MA were fed two types of shrimp feed (38-40\% crude protein, $7.5 \%$ lipid) (see Supplementary data A for more details). Data on the experimental design and rearing performances are presented in Table 1.

\subsection{Life cycle inventory}

Data about the rearing systems were obtained from field measurements: initial and final biomass, feed amounts, inlet water and electricity consumption (Table 1 and Supplementary data A.6). All electricity considered during the experiment was for aeration, since most water arrived by gravity, and pumping was not considered. The water balance (Equation (1)) included water input (volume) from the inlet and rain; however, only the nutrients ( $\mathrm{N}$ and $\mathrm{P}$ ) present in inlet water were considered for the mass balance. Feed $\mathrm{P}$ and crude protein contents were based on package labels (Supplementary data A). C. macropomum $\mathrm{P}$ and crude protein contents were obtained from the literature: $0.7 \%$ and $15 \%$, respectively (Meer et al., 1995). Due to the lack of literature on M. amazonicum, $\mathrm{P}$ and crude protein contents of Macrobrachium rosenbergii (in the same genus) were used for it: $0.226 \%$ and $18.11 \%$, respectively (Sahu et al., 2013). Data for gaseous emissions were also extracted from the literature: methane emissions of $2.47 \mathrm{mg} \mathrm{m}^{-2} \mathrm{~h}^{-1}$ came from a refuge fish pond in a rice-fish experiment (Datta et al., 2009), while ammonia volatilization of $12.5 \%$ and denitrification of $17.4 \%$ of total $\mathrm{N}$ inputs were derived from channel catfish ponds (Gross et al., 2000). The model (assumptions and equations) used to determine the fate of the $\mathrm{N}$ and $\mathrm{P}$ in the systems is described in Supplementary data B, while the inputs and outputs used to build the inventories are presented in Supplementary data C.

Inlet water + Rain water $=$ Evaporation + Seepage + Drained water (harvest)

Background data related to equipment, infrastructure materials, electricity, fuel and transport were obtained from the ecoinvent ${ }^{\circledR}$ 
Table 1

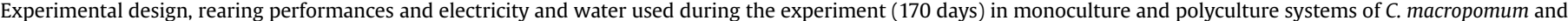

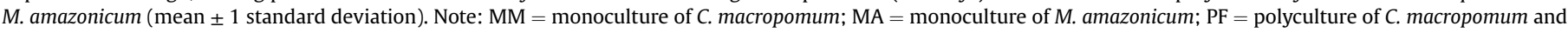

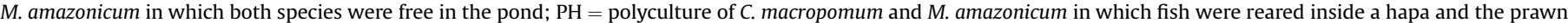

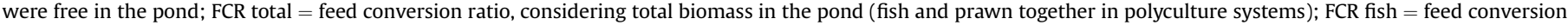
ratio, considering only the fish biomass.

\begin{tabular}{|c|c|c|c|c|}
\hline & MM & MA & $\mathrm{PF}$ & $\mathrm{PH}$ \\
\hline Fish stocking density (fry $\mathrm{m}^{-2}$ ) & 3 & - & 3 & $0.86 \pm 0.1^{\mathrm{a}}$ \\
\hline Prawn stocking density $\left(\mathrm{pl} \mathrm{m}^{-2}\right.$ ) & - & 30 & 30 & 30 \\
\hline Stocked fish biomass $\left(\mathrm{kg} \mathrm{ha}^{-1}\right)$ & 53.2 & - & 53.2 & $15.2 \pm 1.8^{\mathrm{a}}$ \\
\hline Stocked prawn biomass $\left(\mathrm{kg} \mathrm{ha}^{-1}\right)$ & - & 11.3 & 11.3 & 11.3 \\
\hline FCR total (wet weight) & $1.14 \pm 0.04$ & $2.80 \pm 0.08$ & $0.97 \pm 0.01$ & $0.72 \pm 0.16$ \\
\hline FCR fish (wet weight) & $1.14 \pm 0.04$ & - & $1.12 \pm 0.03$ & $1.15 \pm 0.04$ \\
\hline Fish productivity $\left(\mathrm{kg} \mathrm{ha}^{-1}\right)$ & $5386 \pm 945$ & - & $4349 \pm 822$ & $914 \pm 175$ \\
\hline Prawn productivity $\left(\mathrm{kg} \mathrm{ha}^{-1}\right)$ & - & $953 \pm 163$ & $663 \pm 73$ & $551 \pm 91$ \\
\hline Total productivity $\left(\mathrm{kg} \mathrm{ha}^{-1}\right)$ & $5386 \pm 945$ & $953 \pm 163$ & $5011 \pm 869$ & $1465 \pm 267$ \\
\hline Electricity consumption (kwh) & 99.8 & 99.8 & 99.8 & 99.8 \\
\hline Water $\left(\mathrm{m}^{3}\right)$ & $1368 \pm 16$ & $1703 \pm 554$ & $917 \pm 174$ & $1383 \pm 471$ \\
\hline
\end{tabular}

a Stocking density was 120 fish fry per hapa, or $30 \mathrm{fry} \cdot \mathrm{m}^{-3}$.

v3.1 database (default option). For feed ingredients, the modeled data were extracted from life cycle inventories in the INRA UMR SAS and AGRIBALYSE databases after all ecoinvent processes in these inventories had been updated to ecoinvent v3.1. Distances for road transport were estimated using Google Maps ${ }^{\circledR}$. We assumed that each ingredient was transported to the feed factory from the Brazilian city that produced the most of it. The only exceptions were fish oil and fish meal, which were assumed to come from the port of Callao, Peru. Data used for fish oil and fish meal, and the pelletizing and packing processes, were based on the study of Boissy et al. (2011). The fish feed factory is located in Pitangueiras, São Paulo, Brazil, and the prawn feed factory in Sales Oliveira, São Paulo. We also included transport of feed, equipment and materials used in the infrastructure from the cities where they were fabricated to the experimental site.

Data for the M. amazonicum pl inventory was collected at the experimental hatchery in CAUNESP during prawn pl production. The inputs included were feed, water, electricity, fuel, equipment and infrastructure for the three stages: broodstock maintenance, hatchery and nursery. Mass-balance modeling, used to identify the fate of nutrients during the experiment, was adapted for prawn $\mathrm{pl}$ production (Supplementary data C). The feed considered in each stage was the same as that used during the experiment: pellet feed for broodstock maintenance (38\% crude protein, $7.5 \%$ lipid) and powder feed for the nursery ( $40 \%$ crude protein, $7.5 \%$ lipid); see Supplementary data A for more feed details. For the hatchery stage, only brine shrimp (Artemia salina) was considered as feed. Electricity consumption included the air blower responsible for aerating the tanks in the hatchery and nursery for $24 \mathrm{~h}$ and the water heaters and lamps used to maintain the photoperiod.

Data for C. macropomum fry production were obtained from the literature (Guerreiro, 2012). Similar to prawn pl production, fish fry production was divided into the same three stages and included feed inputs for broodstock maintenance (32\% crude protein, $4.5 \%$ lipid) and the nursery ( $45 \%$ crude protein, $7.0 \%$ lipid). The inputs were the same as those for prawn pl, excluding fuel, since no generator was used. For electricity, only consumption by the lights of the feed depot and the packing unit was included. For more information, see Supplementary data $C$.

\subsection{Life cycle impact assessment}

Life cycle impact assessment was based on the CML-IA version 3.02 method (Guinée et al., 2002). Seven impact categories were selected:
- climate change ( $\mathrm{kg} \mathrm{CO} 2$ equivalent), which aggregates greenhouse gas emissions

- acidification ( $\mathrm{kg} \mathrm{SO}_{2}$ equivalent), which aggregates substances that release hydrogen ions into the ecosystem

- eutrophication ( $\mathrm{kg} \mathrm{PO}$ equivalent), which aggregates nutrient emissions that lead to oxygen depletion, impacting aquatic and terrestrial environments

- cumulative energy demand (MJ), which aggregates the energy used from renewable and non-renewable sources (Frischknecht et al., 2004)

- land occupation ( $\mathrm{m}^{2}$ year), which represents the land and time required to produce an output

- water dependence $\left(\mathrm{m}^{3}\right)$, which is the water that forms part of the system, passing through the system and returning to the environment unconsumed (Aubin et al., 2009)

- net primary production use (NPPU, $\mathrm{kg} \mathrm{C}$ ), which aggregates terrestrial and aquatic net primary production that is unavailable for other uses (Papatryphon et al., 2004). The NPPU method for aquatic environments uses trophic level values from a mix of fish species and not from a single species, as does a more recent method (Specific Primary Production Required, Luong et al. (2015), making it less accurate. However, in this study we based fish meal and oil on Peruvian landings, 96\% of which are composed of Peruvian anchovy, Engraulis ringens, (Péron et al., 2010). The trophic level value of this species was 3.63 (Hückstädt et al., 2007), which resulted in a characterization factor for raw fish equal to $47.398 \mathrm{~kg} / \mathrm{kg}$. Moreover, the aquatic NPPU may have little influence on results because the combined percentage of fish oil and fish meal used in the total amount of feed distributed in each rearing system was low (range $=6.3-10.1 \%$ ) (Supplementary data A). According to a review by Cashion et al. (2016), of 17 aquaculture studies that estimated consumption of primary production, 11 chose NPPU as the indicator. Thus, use of NNPU allows us to directly compare results of this study with those of previous studies.

According to the review of Aubin (2013), these categories are the most used in studies of aquaculture systems. To facilitate understanding and discussion of the results, we show the results of only four categories (climate change, eutrophication, cumulative energy demand and land occupation) in the main article (results of the other impact categories are given in supplementary data D and E). Acidification impact is frequently assessed in aquaculture studies (Aubin, 2013; Henriksson et al., 2012), but its patterns are similar to those of cumulative energy demand, which had more interesting discussion points for our study. The LCA was calculated with 
SimaPro ${ }^{\circledR}$ v8.0.5 software (Pré Consultants, Amersfoot, The Netherlands).

We also calculated the edible-protein energy return-oninvestment (ep-EROI), which is the ratio of protein energy harvested to energy input to the system (Vázquez-Rowe et al., 2014). We assumed that energy input to the system equaled cumulative energy demand and adapted calculation of ep-EROI for each species in the polyculture systems (Supplementary data F).

\subsection{Co-product handling approaches}

The polyculture systems (PF and $\mathrm{PH}$ ) delivered $C$. macropomum and M. amazonicum as co-products. Therefore, allocation was performed to quantify the impact of each species in the polyculture. Production of C. macropomum fry and $M$. amazonicum $\mathrm{pl}$ was separated from the system's common inputs, such as water, feed, equipment, etc., and associated with the corresponding species.

The ISO 14044 standard divides the choice of allocation into three successive approaches: (1) expanding the product system, (2) allocation via physical relationships or (3) allocation via other relationships (ISO, 2006a, b). We compared the use of these approaches to estimate impacts of each species in the polyculture systems. The first approach of the standard suggests avoiding allocation; therefore, the system was expanded using monoculturesystem data for the species in the polyculture systems. In the second approach, if allocation cannot be avoided, physical relationships should be applied to divide co-product impacts; we selected mass- and energy-based allocation approaches. In the third approach, if the previous procedures cannot be applied, it is recommended to apply another relationship between the co-products. For this study, we selected economic allocation, which is widely used in aquaculture. We also calculated ep-EROI using both mass and economic allocations to compare the influence of allocation approach.

\subsection{Uncertainty analysis}

The process for determining uncertainty in the production systems included three steps. For primary data, the standard deviation of the three replicates was used in a normal distribution (as suggested by experiment results). For secondary data, the pedigree matrix of Ciroth et al. (2013) was used to quantify uncertainty in the values selected from the literature. We applied a lognormal distribution to results generated from the matrix. For P digestibility by M. amazonicum and economic allocation, maximum and minimum values were selected from a uniform distribution. Monte Carlo (MC) analysis was performed in SimaPro ${ }^{\circledR}$ v8.0.5. A list of the parameters, matrix outcomes and sales prices is given in Supplementary data G.

\subsection{Data analysis}

To compare systems while considering uncertainty, we ran 1000 interactions in pairs in MC analysis. This method indicated the number of times that one system had higher impacts than the other. We considered that the two systems differed if one had higher impacts in at least $90 \%$ of the runs. This method was used to compare impacts of the following: the four systems (MM, MA, PF and $\mathrm{PH}$ ) to each other; system expansion and allocation (mass, energy and economic) vs. the MM and MA monocultures; and the mass, energy and economic allocation approaches. This analysis was performed in SimaPro ${ }^{\circledR}$ v8.0.5.

We excluded correlations between life cycles of the products compared (e.g. MM vs. MA) when running comparative MC analysis. Although Bojacá and Schrevens (2010) concluded that ignoring correlations may overestimate uncertainty in certain impact categories, our results did not show high uncertainty (Supplementary data $\mathrm{H}$ ).

\section{Results}

For all seven impact categories selected, the MA system had the highest impacts (Fig. 2, and Supplementary data D). For eutrophication and water dependence, MA impacts were more than 8 and 7 times as high as those of PF and MM, respectively. PH had the second highest impacts in all categories except for net primary production use, for which MM, PF and PH had similar impacts. Overall, PF and MM had the lowest impacts. Differences between these systems were found for cumulative energy demand and water dependence, for which MM and PF, respectively, had the lowest impact.

Contributions of the rearing systems' key elements (rearing, fish fry, prawn pl, feed, equipment, infrastructure and electricity) varied according to the impact category and to the system (Fig. 3 and Supplementary data D and E). For eutrophication, land occupation and water dependence, the rearing stage itself contributed the most (75\%, 77\% and 97\%, respectively). The second largest contributor for eutrophication and land occupation was feed for $\mathrm{MM}, \mathrm{MA}$ and $\mathrm{PF}$, and (at 6\%) prawn pl for $\mathrm{PH}$.

For climate change, cumulative energy demand and acidification, the main contributors were feed, electricity, prawn pl, fish fry and rearing (the last only for climate change). For climate change, feed was largest contributor, followed by rearing, stocking animals and electricity for the MM, MA and PF systems. For PF, prawn pl and fish fry contributed $15 \%$ each. For PH, contributions were mainly rearing (27\%), prawn pl (23\%) and electricity (19\%). For cumulative energy demand, feed contribution was followed by that of electricity for MM and PF; however, for MA and $\mathrm{PH}$, prawn pl and electricity contributed the most.

Feed contributed $88-98 \%$ of net primary production use of systems, followed by stocking animals, prawn pl and fish fry. For acidification, feed was also the largest contributor for all systems (29-73\%). It is important to highlight that prawn pl was the second highest contributor for MA and PH. For PF, prawn pl and fish fry had contributions of $12 \%$ each.

The MM system had the highest ep-EROI (4.6\%), followed by PF, $\mathrm{PH}$ and MA (3.6, 1.6\% and $0.9 \%$, respectively). For polyculture systems, the allocation approach (mass or economic) had little influence on ep-EROI (Supplementary data D).

\subsection{Co-product handling approaches}

Potential impacts estimated from applying system expansion and allocation approaches to polyculture co-products were divided by species to facilitate comparison to those of monoculture systems (Supplementary data I). Impacts of fish production differed for the two polyculture systems depending on the selected co-product handling approach. In general, impacts of fish from PF were lower or similar to those of MM (Table 2). Nevertheless, impacts of fish from $\mathrm{PH}$ were higher or similar to those of MM in most categories, except for eutrophication and net primary production use under system expansion, whose values were negative. For PH and PF, mass and energy allocation yielded similar impacts in all seven categories; however, both were higher than those using economic allocation.

For prawn, PF also had impacts lower than those of MA for all allocation approaches and system expansion (Table 2). For three categories (eutrophication, net primary production use and water dependence), impacts under system expansion were even negative; however, it is important to highlight its larger standard deviation. For $\mathrm{PH}$, impacts of prawn were similar to or lower than 

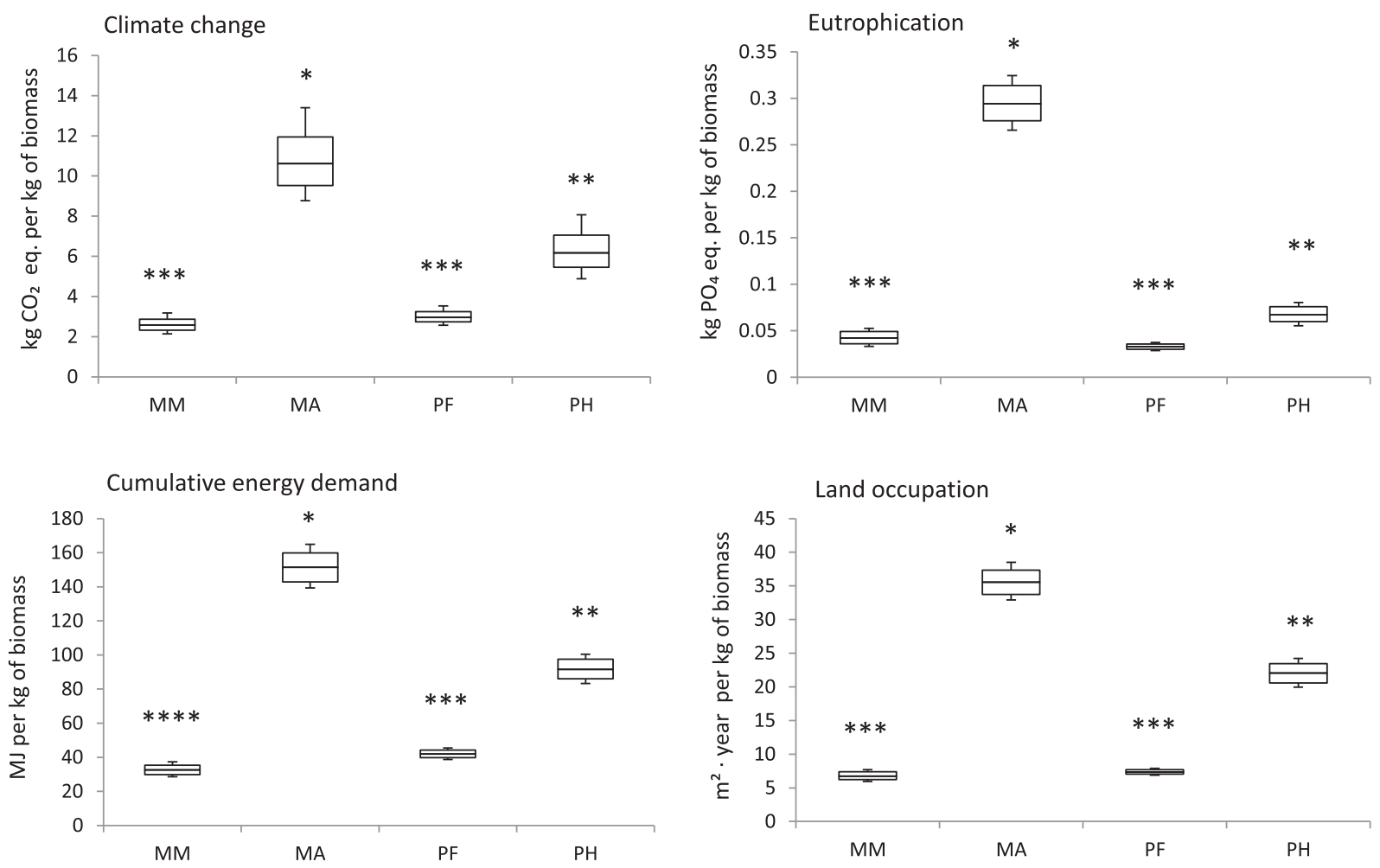

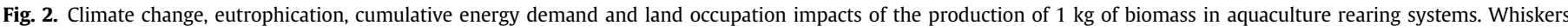

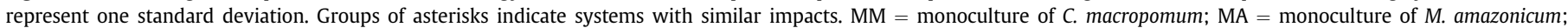

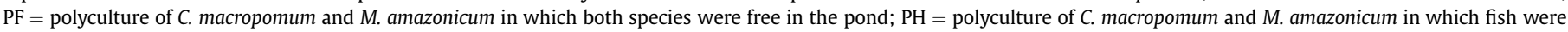
reared inside a hapa cage and prawn were free in the pond; eq = equivalents.
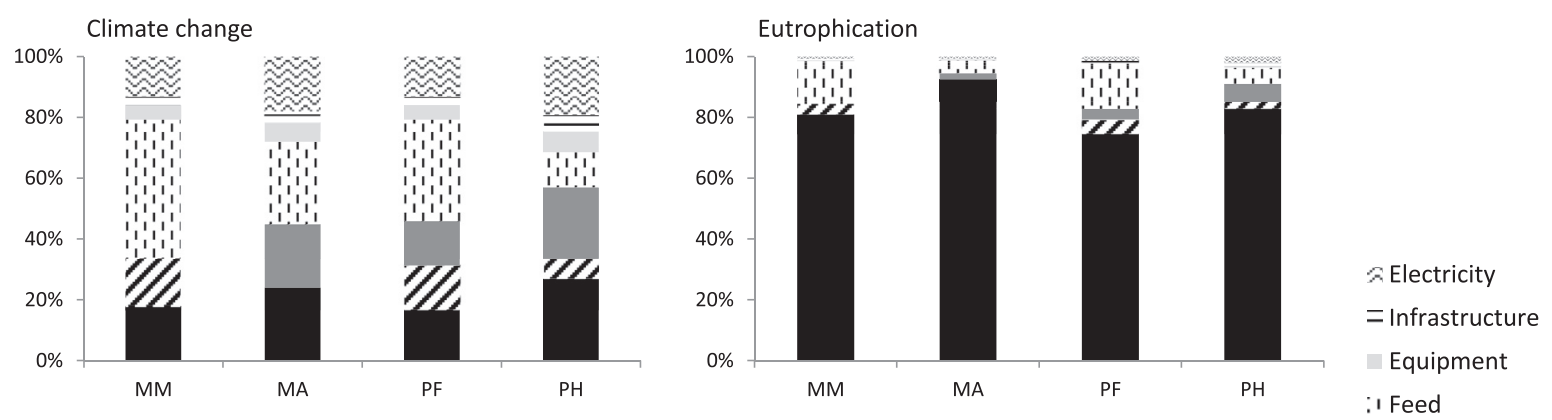

Cumulative energy demand
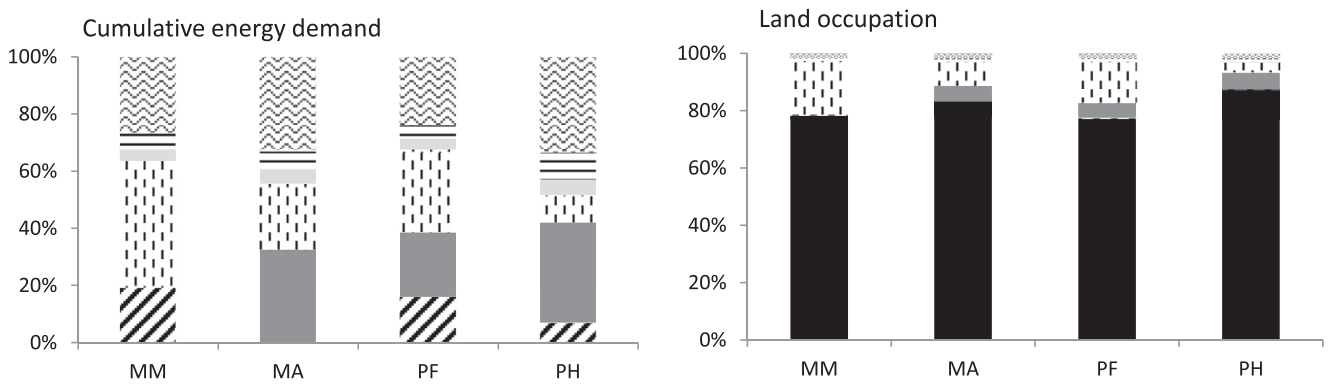

Prawn post-larvae

$\angle$ Fish fry

Rearing

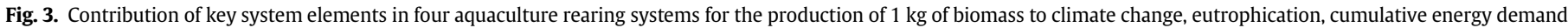

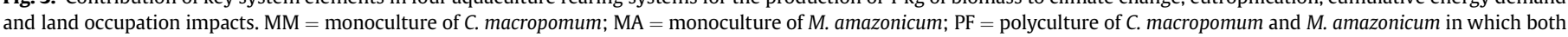
species were free in the pond; $\mathrm{PH}=$ polyculture of $C$. macropomum and $M$. amazonicum in which fish were reared inside a hapa cage and prawn were free in the pond.

those of MA when allocation was applied; relative impacts under system expansion varied from lower to higher according to the impact category (Supplementary data I). Both PF and PH impacts using economic allocation were higher than those using mass and energy allocation, the opposite of the results for fish.

\section{Discussion}

\subsection{Rearing systems}

Results of environmental assessment (Fig. 2) indicate the MA 
Table 2

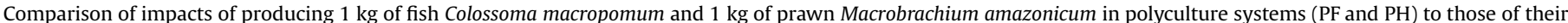

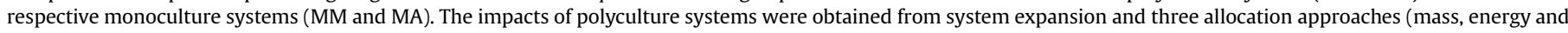

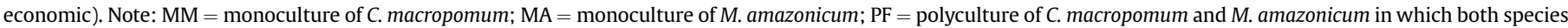
were free in the pond; $\mathrm{PH}=$ polyculture of $\mathrm{C}$. macropomum and $M$. amazonicum in which fish were reared inside a hapa and prawn were free in the pond.

\begin{tabular}{|c|c|c|c|c|}
\hline \multirow[t]{2}{*}{ Co-product approach } & \multicolumn{2}{|c|}{ Colossoma macropomum } & \multicolumn{2}{|c|}{ Macrobrachium amazonicum } \\
\hline & $\mathrm{PF}$ & PH & $\mathrm{PF}$ & $\mathrm{PH}$ \\
\hline System expansion & Lower & Lower/Similar/Higher & Lower & Lower/Similar/Higher \\
\hline Allocation & Similar/Lower & Higher/Similar a & Lower ${ }^{b}$ & Higher/Similar ${ }^{\mathrm{a}}$ \\
\hline
\end{tabular}

${ }^{\text {a }}$ Exception: net primary production use impacts using mass and economic allocation were lower than those of fish monoculture.

b Exception: acidification impacts using economic allocation were similar to those of prawn monoculture (MA).

system had the highest impacts to produce $1 \mathrm{~kg}$ of biomass (considering prawn and fish together in the polyculture systems), followed by PH. The PF and MM systems had the lowest environmental impacts. These results were influenced mainly by the productivity (growth and survival rates), feed quantity and feed conversion ratio (FCR) in each system (Table 1). Productivity itself cannot be used as a parameter to define the most efficient system from an environmental viewpoint; otherwise intensive systems would always be more efficient and environmentally friendly. Studies have shown that intensive systems can have higher impacts per $\mathrm{kg}$ of aquatic product in several categories despite having higher productivity (Ayer and Tyedmers, 2009; Cao et al., 2011; Dekamin et al., 2015; Samuel-Fitwi et al., 2013). It is important to highlight differences in rearing technologies and inputs of these production systems. For example, flow-through systems require more water and area than recirculating systems; however, their electricity consumption is much lower (Dekamin et al., 2015). In the present study, all systems used the same pond-rearing technology and had similar infrastructure and electricity use. Therefore, the impacts of these "fixed" inputs were diluted by the production level of each system, which made MA, which was the least productive, the least environmentally efficient.

In addition to productivity, feed use can explain the impacts. The importance of feed in pond aquaculture has been discussed and demonstrated (Bosma et al., 2011; Cao et al., 2011; Huysveld et al., 2013). Jerbi et al. (2012) found lower impacts from decreasing FCR. A lower FCR not only decreases the amount of feed delivered but also the nutrient losses released to the bottom and into the water. In non-fed aquaculture ponds, natural food is essential for reared animal nutrition (Spataru et al., 1983), while in fed ponds, it is a supplementary source of food, which reduces dependence on the feed and decreases the FCR. The importance of natural food is inversely proportional to system intensity; organisms in highly intensive systems rely only on feed as a nutrient source. According to stable isotope analysis, both species are able to rely on multiple sources of nutrients, such as formulated feed, plankton and, for prawn, also sediment and feces, (G. Costa, CAUNESP, pers. comm.). Therefore, the lower productivity and higher FCR of the MA system compared to the other systems explain its higher impacts.

The PH system, despite having the lowest FCR and quantity of feed delivered, did not have impacts similar to those of PF and MM, since its productivity was one-third as high as theirs. The only category for which $\mathrm{PH}$ had the lowest impact was net primary production use, because the small amount of feed and stocking fish fry compensated for low productivity. Differences between PF and MM lay in the amount of feed and FCR (both higher in MM) and stocking animals (higher in PF), since PF added the impacts of prawn pl to those of fish fry. Despite the differences, PF and MM had similar environmental impacts overall to produce $1 \mathrm{~kg}$ of biomass.

Fish was the key player in this experiment. Despite similar FCR for fish in PF, PH and MM (Table 1), the final biomass was much lower in PH. Similar fish production in PF and MM led to similar environmental impacts. Adding more hapas to $\mathrm{PH}$ to produce as much fish biomass as in PF and MM would probably reduce impacts of $\mathrm{PH}$; however, this strategy should be tested to assess system performance. MA had the highest productivity considering only prawn biomass; however, production of this species alone is not justified from an environmental viewpoint. M. amazonicum has great aquaculture potential (Moraes-Valenti and Valenti, 2010), and the present results encourage adding it as a secondary species in polyculture systems. Nevertheless, more studies are necessary to improve the results of $M$. amazonicum in captive-rearing conditions.

Differences in ep-EROI among systems also demonstrate the importance of fish in the system, mainly because fish have a higher percentage of edible meat than prawn (61\% vs. $45 \%$, respectively). The ep-EROI in this study $(0.9-4.6 \%)$ were lower than those of other aquaculture fish, such as trout (9.1-14.1\%) (Lasner et al., 2016) and salmon (7.8-17.8\%) (Pelletier and Tyedmers, 2007), but they lay within the range $(0.8-14.9 \%)$ of those of seafood caught with a variety of fishing techniques (Vázquez-Rowe et al., 2014). Comparisons should be made carefully, since energy inputs to systems vary among studies, as do energy concentrations of protein (e.g. $16.7 \mathrm{MJ} \mathrm{kg}^{-1}$ (this study), $16.73 \mathrm{MJ} \mathrm{kg}^{-1}$ (Vázquez-Rowe et al., 2014), $23.6 \mathrm{MJ} \mathrm{kg}^{-1}$ (Lasner et al., 2016; Pelletier and Tyedmers, 2007)).

\subsection{Specific characteristics of the experiment}

The study was conducted at the Freshwater Prawn Sector of CAUNESP, dedicated to experiments of different stages of prawn production. Unlike a commercial farm, in which the infrastructure and equipment are installed to produce specific amounts of products, the experimental lab was built to study production at multiple scales. The main equipment in this study was anti-bird nets, a platform (to measure water parameters and deliver feed) and aerators. The first two are not commonly used on commercial fish farms, and the latter has the capacity to aerate a $500 \mathrm{~m}^{2}$ pond (a small scale pond). The pond infrastructure (inlet channel, monk and outlet pipes) is designed to support a pond five times as large. Therefore, some impacts related to infrastructure may be higher than those of a commercial facility. Some LCA aquaculture studies exclude impacts related to infrastructure (Bosma et al., 2011; Dekamin et al., 2015; Huysveld et al., 2013). Doing so in this study would have changed the magnitudes of certain impacts because infrastructure and equipment together contribute $7-12 \%$ of climate change, $9-15 \%$ of cumulative energy demand and $7-18 \%$ of acidification. Scaling up the system would probably reduce certain impacts, as observed in the study of Gavankar et al. (2014); however, the advantages of scaling up depend on the type of industry (Canbäck et al., 2006). In aquaculture, especially in pond systems, scaling up to a 1 ha pond would probably decrease infrastructure and equipment impacts, but may also decrease system efficiency. In larger ponds, it is more challenging to determine 
fish appetite and the amount of feed to deliver. Mistakes in feed management could decrease fish growth and overall system performance, since feed is a key contributor to several impact categories.

The impact of fish fry was probably higher than that on commercial C. macropomum farms, since delivery included air and road transport. Air transport was necessary because the hatchery (Presidente Figueiredo, Amazonas) lies more than $3600 \mathrm{~km}$ by road from the experimental station (Jaboticabal, Sao Paulo). Farms are usually located near hatcheries to reduce the cost and stress of transport; consequently, shorter distances indicate lower environmental impacts. The air transport in this study contributed more than $85 \%$ of fish fry impacts for climate change, cumulative energy demand and acidification. In these impact categories, the contribution of fish fry to the total impact ranged from 7 to $16 \%, 7-19 \%$ and $8-12 \%$, respectively (Fig. 3). Impacts of fish fry production vary greatly in the literature. Jerbi et al. (2012) found large contributions from the hatchery ( $>10 \%$ of the three impact categories), but impacts were lower in other studies (Aubin et al., 2015; Dekamin et al., 2015; Pelletier and Tyedmers, 2010). None of the studies considered air transport; therefore, the differences in impact are related to the differences in rearing technology of the species and choices in the life cycle inventory.

For prawn pl production, contribution to impacts for $1 \mathrm{~kg}$ of final product varied among systems: $15-23 \%$ of climate change, $23-35 \%$ of cumulative energy demand and 12-27\% of acidification (Fig. 3). These contributions were higher than those of marine shrimp hatcheries in monoculture (Cao et al., 2011) and polyculture rearing systems (Aubin et al., 2015), for which impacts were less than 5\% and $8 \%$, respectively, in all categories. Prawn pl production was highly influenced by the electricity consumed; its contribution was high to climate change (70\%), cumulative energy demand (82\%) and acidification (60\%). The high electricity consumption can be explained by the system's efficiency; as previously mentioned, the facility was not specifically designed to perform this experiment.

\subsection{Co-product handling approaches}

Defining the most appropriate allocation approach for systems producing two or more co-products still generates discussion. Studies addressing the reasons to select a given allocation approach have already been published (Ayer et al., 2007; Pelletier and Tyedmers, 2011; van der Werf and Nguyen, 2015). The aim of this study was not to debate the best form of allocation, but to discuss the results from the three co-product handling approaches proposed by the ISO (ISO, 2006b) standard.

Despite the ISO standard recommendation to consider system expansion first, it is not frequently used in seafood LCA. Most studies use allocation rules. In the present study, impacts of monoculture systems (MM and MA) were used to expand those of the polyculture systems. The results differed according to the allocation approach applied (considering fish and prawn as a single output). Producing $1 \mathrm{~kg}$ of fish in MM and $1 \mathrm{~kg}$ of biomass in PF (prior allocation) had similar impacts; however, $1 \mathrm{~kg}$ of fish in PF without the impact of prawn had, in general, lower impacts than that in MM.

Impacts using mass and energy allocation were similar for all categories because the animals differed little in energy concentration (Table G.2 in Supplementary data). Some authors suggest that allocation based on energy content is the most appropriate for LCA (Ayer et al., 2007; Pelletier and Tyedmers, 2011), but when species have similar energy concentrations, simple mass allocation provides similar results. Economic allocation, despite being the last option in the standard, is the most frequently used for seafood production. This allocation is driven by the market price of each species. In the present study, prawn cost more than three times as much per kg as fish (Table G.2 in Supplementary data). Therefore, impacts of producing $1 \mathrm{~kg}$ of fish using economic allocation were lower than those using mass and energy allocation; the opposite was observed for $1 \mathrm{~kg}$ of prawn. A similar situation was described in the polyculture study of Aubin et al. (2015). Using economic allocation in the present study, PF had lower impacts than MM to produce $1 \mathrm{~kg}$ of fish.

In the present study, differences in impact among allocation approaches were clear. The lower impacts of PF than MM using economic allocation were not found when using mass and energy allocation (system expansion impacts were not considered). However, it is important to note that the price of a given species can differ by region, season and year, which can influence results. Studies using economic allocation should be compared with caution.

\subsection{Uncertainty}

The uncertainty in this study was in a range similar to that described by Dekamin et al. (2015) and lower than that found by Aubin et al. (2015). These differences can be explained by homogeneity in rearing practices; Aubin et al. (2015) found that sources of uncertainty included differences between farm practices in the same system (size, productivity and species mix). Dekamin et al. (2015) analyzed production systems in which species and conditions in each system were relatively similar. In the present study, less uncertainty was found for the PF and MM systems.

Sources of uncertainty for all impact categories include variability among the three replicates of each system, the inherent variability already present in the ecoinvent database and the assumptions made for mass-balance modeling. For net primary production use and water dependence, uncertainty was related to the variability among replicates. Water dependence was directly influenced by water use, which is linked to the evaporation and seepage rates of each pond. One of the ponds in the MA and PH systems had higher seepage rates than average, which increased the uncertainty in water dependence but did not change the overall results.

Another system uncertainty relates to the model used. Digestibility determines the fate of nutrients and the amounts of nutrients in the water column (digestible wastes) and sediment (non-digestible wastes) (Guillaume et al., 1999). The lack of literature data on $\mathrm{P}$ digestibility for prawn species reduces the accuracy of estimates of the fate of P. However, the overall impacts of the system remain the same, since water and sediment were not reused as a nutrient source for other activities; both were considered waste in the system.

The parameters with higher uncertainties in the pedigree matrix were gaseous emissions to the atmosphere. The three processes considered were denitrification, ammonia volatilization and methane emissions, the first two of which directly influence eutrophication and the last of which influences climate change. Denitrification and ammonia volatilization rates were based on Gross et al. (2000), who measured a loss of $40 \%$ of N inputs through these processes. In the literature, variability in gaseous emissions from ponds is huge: Páez-Osuna et al. (1999) found them equal to $66 \%$ of total $\mathrm{N}$ inputs, while they were $<5 \%$ in other studies (Adhikari et al., 2014; Rahman et al., 2008). Jiménez-Montealegre et al. (2005) even closed the $\mathrm{N}$ cycle with no $\mathrm{N}$ emissions to the air.

Methane emissions had the highest uncertainty in the pedigree matrix due to their huge variability. In a review of rice fields in India, methane emissions ranged from 5 to $1650 \mathrm{~kg} \mathrm{ha}^{-1}$ (Jain et al., 2004). High variability in methane emissions is also expected in aquaculture ponds. To our knowledge, no published studies exist 
about emissions in fed aquaculture ponds. Due to this limitation, we used a value from a refuge fish pond in a rice-fish experiment (Datta et al., 2009) in which the pond was $1.75 \mathrm{~m}$ deep, no rice plants grew, and fish were fed (Supplementary data J). The uncertainty was determined by the variability in emissions from the integrated rice-fish system (Bhattacharyya et al., 2013; Datta et al., 2009; Frei and Becker, 2005; Frei et al., 2007). The characteristics required for methane production, such as temperature, humidity and anaerobic soil conditions (Jain et al., 2004), were relatively similar in both systems. However, differences in species reared, stocking density and type of feed between the production systems may have yielded some differences in methane emissions (Supplementary data J). The methane emissions used can thus be discussed in light of these differences. Aquatic environments such as lakes and mangroves are known as methane emission hotspots (Bastviken et al., 2004; Purvaja and Ramesh, 2000; Xing et al., 2005). The high probability that aquaculture ponds are a source of methane, in addition to methane's significant role in climate change (IPCC, 2014), led us to include its emission. In our study, methane emissions represent the total contribution of the rearing stage to climate change (17-27\%). If we omit them, the main contributors to climate change become feed, electricity, fish fry and prawn pl. Although excluding methane emissions would decrease climate change impacts, MM and PF would remain the most efficient systems, while MA would remain the least efficient system. The overall conclusions of this study would not change if methane emissions were excluded; however, due to their importance to climate change, it is important to include them in calculations to stimulate consideration of them in future studies.

\section{Conclusion}

The LCA helped determine that the C. macropomum monoculture and the polyculture in which both C. macropomum and M. amazonicum were reared free in the pond are the systems with lower environmental impacts per $\mathrm{kg}$ of biomass produced. However, when the species were analyzed separately using economic allocation, the polyculture had lower impacts than the monoculture. The M. amazonicum monoculture had the highest impacts for all categories, which indicates there is room for improvement in the domestication of this species and in the rearing system. In addition, LCA enabled identifying the system elements that were the main contributors to impacts: feed and the rearing system. Impacts of these production systems can be significantly reduced if these elements are improved.

Small-scale experiments do not always represent the reality of a commercial farm; therefore, application of LCA at a commercial scale would tend to decrease overestimates of infrastructure, equipment and stocking animals. Moreover, additional measurements of gaseous emissions from aquaculture ponds would improve estimates of emission rates and reduce the uncertainty in them.

LCA offers a wide range of options and decisions to its practitioners regarding the scope, inventory data, impact categories and allocation approach. This freedom of choice has a huge impact on the final results, rendering comparison of different studies difficult. The scientific community should reach a consensus to strengthen LCA studies and increase the acceptance of LCA.

\section{Acknowledgments}

The authors thank the Fundação de Amparo à Pesquisa do Estado de São Paulo (Project: 10/51271-6) and the Coordenação de Aperfeiçoamento de Pessoal de Nível Superior (1639314) for financial support. We also would like to thank Prof. Dr. Wagner
Cotroni Valenti, head of the Freshwater Prawn Sector, Prof. Dr. Sergio Ricardo Batlouni, coordinator of the FAPESP project and all the students who contributed to the experiment. The authors thank Michelle and Michael Corson for proofreading the manuscript's English.

\section{Appendix A. Supplementary data}

Supplementary data related to this article can be found at http:// dx.doi.org/10.1016/j.jclepro.2017.04.059.

\section{References}

Adhikari, S., Sahu, B.C., Mahapatra, A.S., Dey, L., 2014. Nutrient budgets and effluent characteristics in giant freshwater prawn (Macrobrachium rosenbergii) culture ponds. Bull. Environ. Contam. Toxicol. 92, 509-513. http://dx.doi.org/10.1007/ s00128-014-1227-4.

Aubin, J., 2013. Life Cycle Assessment as applied to environmental choices regarding farmed or wild-caught fish. CAB Rev. Perspect. Agric. Vet. Sci. Nutr. Nat. Resour. 8 http://dx.doi.org/10.1079/PAVSNNR20138011.

Aubin, J., Baruthio, A., Mungkung, R., Lazard, J., 2015. Environmental performance of brackish water polyculture system from a life cycle perspective: a Filipino case study. Aquaculture 435, 217-227. http://dx.doi.org/10.1016/j.aquaculture. 2014.09.019.

Aubin, J., Papatryphon, E., van der Werf, H.M.G., Chatzifotis, S., 2009. Assessment of the environmental impact of carnivorous finfish production systems using life cycle assessment. J. Clean. Prod. 17, 354-361. http://dx.doi.org/10.1016/ j.jclepro.2008.08.008.

Ayer, N.W., Tyedmers, P.H., 2009. Assessing alternative aquaculture technologies: life cycle assessment of salmonid culture systems in Canada. J. Clean. Prod. 17, 362-373. http://dx.doi.org/10.1016/j.jclepro.2008.08.002.

Ayer, N.W., Tyedmers, P.H., Pelletier, N.L., Sonesson, U., Scholz, A., 2007. Co-product allocation in life cycle assessments of seafood production systems: review of problems and strategies. Int. J. Life Cycle Assess. 12, 480-487. http://dx.doi.org/ 10.1007/s11367-006-0284-2.

Bastviken, D., Cole, J., Pace, M., Tranvik, L., 2004. Methane emissions from lakes: dependence of lake characteristics, two regional assessments, and a global estimate. Glob. Biogeochem. Cycles 18, 1-12. http://dx.doi.org/10.1029/ 2004GB002238.

Bhattacharyya, P., Sinhababu, D.P., Roy, K.S., Dash, P.K., Sahu, P.K., Dandapat, R., Neogi, S., Mohanty, S., 2013. Effect of fish species on methane and nitrous oxide emission in relation to soil $\mathrm{C}, \mathrm{N}$ pools and enzymatic activities in rainfed shallow lowland rice-fish farming system. Agric. Ecosyst. Environ. 176, 53-62. http://dx.doi.org/10.1016/j.agee.2013.05.015

Boaventura, R., Pedro, A., Coimbra, J., Lencastre, E., 1997. Trout farm effluents: characterization and impact on the receiving streams. Environ. Pollut. 95, 379-387.

Boissy, J., Aubin, J., Drissi, A., van der Werf, H.M.G., Bell, G.J., Kaushik, S.J., 2011 Environmental impacts of plant-based salmonid diets at feed and farm scales. Aquaculture 321, 61-70. http://dx.doi.org/10.1016/j.aquaculture.2011.08.033.

Bojacá, C.R., Schrevens, E., 2010. Parameter uncertainty in LCA: stochastic sampling under correlation. Int. J. Life Cycle Assess. 15, 238-246. http://dx.doi.org/ 10.1007/s11367-010-0150-0.

Bosma, R., Anh, P.T., Potting, J., 2011. Life cycle assessment of intensive striped catfish farming in the Mekong Delta for screening hotspots as input to environmental policy and research agenda. Int. J. Life Cycle Assess. 16, 903-915. http://dx.doi.org/10.1007/s11367-011-0324-4.

Boyd, C.E., Tucker, C.S., 1998. Pond Aquaculture Water Quality Management. Kluwer Academic Publishers, Boston.

Canbäck, S., Samouel, P., Price, D., 2006. Do diseconomies of scale impact firm size and performance? A theoretical and empirical overview. J. Manag. Econ. 4 27-70.

Cao, L., Diana, J.S., Keoleian, G.A., Lai, Q., 2011. Life cycle assessment of Chinese shrimp farming systems targeted for export and domestic sales. Environ. Sci. Technol. 45, 6531-6538. http://dx.doi.org/10.1021/es104058z.

Cashion, T., Hornborg, S., Ziegler, F., Hognes, E.S., Tyedmers, P., 2016. Review and advancement of the marine biotic resource use metric in seafood LCAs: a case study of Norwegian salmon feed. Int. J. Life Cycle Assess. 21, 1106-1120. http:// dx.doi.org/10.1007/s11367-016-1092-y.

Ciroth, A., Muller, S., Weidema, B., Lesage, P., 2013. Empirically based uncertainty factors for the pedigree matrix in ecoinvent. Int. J. Life Cycle Assess. 1-11. http:// dx.doi.org/10.1007/s11367-013-0670-5.

Datta, A., Nayak, D.R., Sinhababu, D.P., Adhya, T.K., 2009. Methane and nitrous oxide emissions from an integrated rainfed rice-fish farming system of Eastern India. Agric. Ecosyst. Environ. 129, 228-237. http://dx.doi.org/10.1016 j.agee.2008.09.003.

de Araujo, M.C., Valenti, W.C., 2007. Feeding habit of the Amazon river prawn Macrobrachium amazonicum larvae. Aquaculture 265, 187-193. http:// dx.doi.org/10.1016/j.aquaculture.2007.01.016.

Dekamin, M., Veisi, H., Safari, E., Liaghati, H., Khoshbakht, K., Dekamin, M.G., 2015. Life cycle assessment for rainbow trout (Oncorhynchus mykiss) production 
systems: a case study for Iran. J. Clean. Prod. 91, 43-55. http://dx.doi.org/ 10.1016/j.jclepro.2014.12.006.

Diana, J.S., 2009. Aquaculture production and biodiversity conservation. Bioscience 59, 27-38. http://dx.doi.org/10.1525/bio.2009.59.1.7.

Efole Ewoukem, T., Aubin, J., Mikolasek, O., Corson, M.S., Tomedi Eyango, M., Tchoumboue, J., Van Der Werf, H.M.G., Ombredane, D., 2012. Environmental impacts of farms integrating aquaculture and agriculture in Cameroon. J. Clean. Prod. 28, 208-214. http://dx.doi.org/10.1016/j.jclepro.2011.11.039.

FAO, 2016. The State of World Fisheries and Aquaculture 2016 (Contributing to food security and nutrition for all. Rome).

FAO, 2014. The State of World Fisheries and Aquaculture. Food and Agriculture Oraganization of the United Nations, Rome doi:92-5-105177-1.

Frei, M., Becker, K., 2005. Integrated rice-fish production and methane emission under greenhouse conditions. Agric. Ecosyst. Environ. 107, 51-56. http:// dx.doi.org/10.1016/j.agee.2004.10.026.

Frei, M., Razzak, M.A., Hossain, M.M., Oehme, M., Dewan, S., Becker, K., 2007. Methane emissions and related physicochemical soil and water parameters in rice-fish systems in Bangladesh. Agric. Ecosyst. Environ. 120, 391-398. http:// dx.doi.org/10.1016/j.agee.2006.10.013.

Frischknecht, R., Jungbluth, N., Althaus, H.J., Doka, G., Dones, R., Hirschier, R., Hellweg, S., Humbert, S., Margni, M., Nemecek, T., Speilmann, M., 2004. Implementation of Life Cycle Impact Assessment Methods (Ecoinvent report. Dübendorf).

Gavankar, S., Suh, S., Keller, A.A., 2014. The role of scale and technology maturity in life cycle assessment of emerging technologies: a case study on carbon nanotubes. J. Ind. Ecol. 19, 51-60. http://dx.doi.org/10.1111/jiec.12175.

Gross, a, Boyd, C.E., Wood, C.W., 2000. Nitrogen transformations and balance in channel catfish ponds. Aquac. Eng. 24, 1-14. http://dx.doi.org/10.1016/S01448609(00)00062-5.

Guerreiro, L.R., 2012. Custos de produção, análise econômica e gerencial em unidade de produção de alevinos de peixes reofílicos: estudo de caso em Rondônia. Universidade Federal do Rio Grande do Sul.

Guillaume, J., Kaushik, S., Bergot, P., Métailler, R., 1999. Nutrition et alimentation des poissons et crustacés. INRA, Paris.

Guinée, J.B., Gorrée, M., Heijungs, R., Huppes, G., Kleijn, R., de Koning, A., van Oers, L., Wegener Sleeswijk, A., Suh, S., Udo de Haes, H.A., de Bruijn, H., van Duin, R., Huijbregts, M.A.J., 2002. Handbook on Life Cycle Assessment: Operational Guide to ISO Standards. Kluwer Academic Publishers, Dordrecht, the Netherlands.

Henriksson, P.J.G., Guinée, J.B., Heijungs, R., De Koning, A., Green, D.M., 2014. A protocol for horizontal averaging of unit process data - including estimates for uncertainty. Int. J. Life Cycle Assess. 19, 429-436. http://dx.doi.org/10.1007/ s11367-013-0647-4.

Henriksson, P.J.G., Guinée, J.B., Kleijn, R., De Snoo, G.R., 2012. Life cycle assessment of aquaculture systems-A review of methodologies. Int. J. Life Cycle Assess. 17, 304-313. http://dx.doi.org/10.1007/s11367-011-0369-4.

Hückstädt, L.A., Rojas, C.P., Antezana, T., 2007. Stable isotope analysis reveals pelagic foraging by the Southern sea lion in central Chile. J. Exp. Mar. Bio. Ecol. 347, 123-133. http://dx.doi.org/10.1016/j.jembe.2007.03.014.

Huysveld, S., Schaubroeck, T., De Meester, S., Sorgeloos, P., Van Langenhove, H., Van Linden, V., Dewulf, J., 2013. Resource use analysis of Pangasius aquaculture in the Mekong delta in Vietnam using exergetic life cycle assessment. J. Clean. Prod. 51, 225-233. http://dx.doi.org/10.1016/j.jclepro.2013.01.024.

IBGE, 2014. Produção da Pecuária Municipal. Rio de Janeiro.

IPCC, 2014. Climate Change 2014: Synthesis Report. Contribution of Working Groups I, II and III to the Fifth Assessment Report of the Intergovernmental Panel on Climate Change. IPCC, Geneva, Switzerland.

ISO, 2006a. ISO 14040: Environmental Management - Life Cycle Assessment Principles and Framework (Genebra)

ISO, 2006b. ISO 14044: Environmental Management - Life Cycle Assessment - Requirements and Guidelines (Genebra).

Jain, N., Pathak, H., Mitra, S., Bhatia, A., 2004. Emission of methane from rice fields a review. J. Sci. Ind. Res. (India) 63, 101-115.

Jegatheesan, V., Shu, L., Visvanathan, C., 2011. Aquaculture effluent: impacts and remedies for protecting the environment and human health. Encycl. Environ. Heal 123-135.

Jerbi, M.A., Aubin, J., Garnaoui, K., Achour, L., Kacem, A., 2012. Life cycle assessment (LCA) of two rearing techniques of sea bass (Dicentrarchus labrax). Aquac. Eng. 46, 1-9. http://dx.doi.org/10.1016/j.aquaeng.2011.10.001.

Jiménez-Montealegre, R., Avnimelech, Y., Verreth, J.A.J., Verdegem, M.C.J., 2005 Nitrogen budget and fluxes in Colossoma macropomum ponds. Aquac. Res. 36 8-15. http://dx.doi.org/10.1111/j.1365-2109.2004.01174.x.

Joyni, M.J., Kurup, B.M., Avnimelech, Y., 2011. Bioturbation as a possible means for increasing production and improving pond soil characteristics in shrimp-fish brackish water ponds. Aquaculture 318, 464-470. http://dx.doi.org/10.1016 j.aquaculture.2011.05.019.

Kadir, A., Wahab, M.A., Milstein, A., Hossain, M.A., Seraji, M.T.I., 2007. Effects of silver carp and the small indigenous fish mola Amblypharyngodon mola and punti Puntius sophore on fish polyculture production. Aquaculture 273, 520-531. http://dx.doi.org/10.1016/j.aquaculture.2007.07.012.

Lasner, T., Brinker, A., Nielsen, R., Rad, F., 2016. Establishing a benchmarking for fish farming - profitability, productivity and energy efficiency of German, Danish and Turkish rainbow trout grow-out systems. Aquac. Res. 1-15. http:// dx.doi.org/10.1111/are.13144.
Lorenzen, K., Struve, J., Cowan, V.J., 1997. Impact of farming intensity and water management on nitrogen dynamics in intensive pond culture: a mathematical model applied to Thai commercial shrimp farms. Aquac. Res. 28, 493-507. http://dx.doi.org/10.1111/j.1365-2109.1997.tb01068.x.

Luong, A.D., Schaubroeck, T., Dewulf, J., De Laender, F., 2015. Re-evaluating primary biotic resource use for marine biomass production: a new calculation framework. Environ. Sci. Technol. 49, 11586-11593. http://dx.doi.org/10.1021/ acs.est.5b02515.

Maciel, C.R., Valenti, W.C., 2009. Biology, fisheries, and aquaculture of the Amazon River prawn Macrobrachium amazonicum: a review. Nauplius 17, 61-79.

Meer, M.B. Van Der, Machiels, M., Verdegem, M., 1995. The effect of dietary protein level on growth, protein utilization and body composition of Colossoma macropomum (Cuvier). Aquaculture 26, 901-909. http://dx.doi.org/10.1111/j.13652109.1995.tb00885.x.

Moraes-Valenti, P.M., Valenti, W.C., 2010. Culture of the Amazon River prawn Macrobrachium amazonicum. In: New, M.B., Valenti, W.C., Tidwell, J.H., D'Abramo, L.R., Kutty, M.N. (Eds.), Freshwater Prawns - Biology and Farming. Blackwell Publishing Ltd, pp. 485-501.

Naylor, R.L., Goldburg, R.J., Primavera, J.H., Kautsky, N., Beveridge, M.C., Clay, J., Folke, C., Lubchenco, J., Mooney, H., Troell, M., 2000. Effect of aquaculture on world fish supplies. Nature 405, 1017-1024. http://dx.doi.org/10.1038/ 35016500 .

Páez-Osuna, F., Guerrero-Galván, S., Ruiz-Fernández, A., 1999. Discharge of nutrients from shrimp farming to coastal waters of the Gulf of California. Mar. Pollut. Bull. 38, 585-592.

Papatryphon, E., Petit, J., Kaushik, S.J., van der Werf, H., 2004. Environmental impact assessment of salmonid feeds using life cycle assessment (LCA). AMBIO A J. Hum. Environ. 33, 316-323.

Pelletier, N., Tyedmers, P., 2011. An ecological economic critique of the use of market information in life cycle assessment research. J. Ind. Ecol. 15, 342-354. http:// dx.doi.org/10.1111/j.1530-9290.2011.00337.x.

Pelletier, N., Tyedmers, P., 2010. Life cycle assessment of frozen tilapia fillets from indonesian lake-based and pond-based intensive aquaculture systems. J. Ind. Ecol. 14, 467-481. http://dx.doi.org/10.1111/j.1530-9290.2010.00244.x.

Pelletier, N., Tyedmers, P., 2007. Feeding farmed salmon: is organic better? Aquaculture 272, 399-416. http://dx.doi.org/10.1016/j.aquaculture.2007.06.024.

Péron, G., François Mittaine, J., Le Gallic, B., 2010. Where do fishmeal and fish oil products come from? An analysis of the conversion ratios in the global fishmeal industry. Mar. Policy 34, 815-820. http://dx.doi.org/10.1016/j.marpol.2010. 01.027.

Phong, L.T., de Boer, I.J.M., Udo, H.M.J., 2011. Life cycle assessment of food production in integrated agriculture-aquaculture systems of the Mekong Delta. Livest. Sci. 139, 80-90. http://dx.doi.org/10.1016/j.livsci.2011.03.015.

Purvaja, R., Ramesh, R., 2000. Human impacts on methane emission from mangrove ecosystems in India. Reg. Environ. Chang. 1, 86-97. http://dx.doi.org/10.1007/ PL00011537.

Rahman, M.M., Jo, Q., Gong, Y.G., Miller, S.A., Hossain, M.Y., 2008. A comparative study of common carp (Cyprinus carpio L.) and calbasu (Labeo calbasu Hamilton) on bottom soil resuspension, water quality, nutrient accumulations, food intake and growth of fish in simulated rohu (Labeo rohita Hamilton) ponds. Aquaculture 285, 78-83. http://dx.doi.org/10.1016/j.aquaculture.2008.08.002.

Sahu, B.C., Adhikari, S., Mahapatra, A.S., Dey, L., 2013. Carbon, nitrogen, and phosphorus budget in scampi (Macrobrachium rosenbergii) culture ponds. Environ. Monit. Assess. 185, 10157-10166. http://dx.doi.org/10.1007/s10661-013-3320-2.

Samuel-Fitwi, B., Nagel, F., Meyer, S., Schroeder, J.P., Schulz, C., 2013. Comparative life cycle assessment (LCA) of raising rainbow trout (Oncorhynchus mykiss) in different production systems. Aquac. Eng. 54, 85-92. http://dx.doi.org/10.1016/ j.aquaeng.2012.12.002.

Santos, A.A.O., Aubin, J., Corson, M.S., Valenti, W.C., Camargo, A.F.M., 2015. Comparing environmental impacts of native and introduced freshwater prawn farming in Brazil and the influence of better effluent management using LCA. Aquaculture 444, 151-159. http://dx.doi.org/10.1016/j.aquaculture.2015.03.006.

Spataru, P., Wohlfarth, G.W., Hulata, G., 1983. Studies on the natural food of different species in intensively manured polyculture ponds. Aquaculture 35, 283-298. http://dx.doi.org/10.1016/0044-8486(83)90101-1.

van der Werf, H.M.G., Nguyen, T.T.H., 2015. Construction cost of plant compounds provides a physical relationship for co-product allocation in life cycle assessment. Int. J. Life Cycle Assess. 20, 777-784. http://dx.doi.org/10.1007/s11367015-0872-0.

Vázquez-Rowe, I., Villanueva-Rey, P., Moreira, M.T., Feijoo, G., 2014. Edible protein energy return on investment ratio (ep-EROI) for Spanish seafood products. Ambio 43, 381-394. http://dx.doi.org/10.1007/s13280-013-0426-2.

Wahab, M.A., Kadir, A., Milstein, A., Kunda, M., 2011. Manipulation of species combination for enhancing fish production in polyculture systems involving major carps and small indigenous fish species. Aquaculture 321, 289-297. http://dx.doi.org/10.1016/j.aquaculture.2011.09.020.

Whitmarsh, D.J., Cook, E.J., Black, K.D., 2006. Searching for sustainability in aquaculture: an investigation into the economic prospects for an integrated salmonmussel production system. Mar. Policy 30, 293-298. http://dx.doi.org/10.1016/ j.marpol.2005.01.004.

Xing, Y., Xie, P., Yang, H., Ni, L., Wang, Y., Rong, K., 2005. Methane and carbon dioxide fluxes from a shallow hypereutrophic subtropical Lake in China. Atmos. Environ. 39, 5532-5540. http://dx.doi.org/10.1016/j.atmosenv.2005.06.010. 